\title{
Phloretin exhibits an anticancer effect and enhances the anticancer ability of cisplatin on non-small cell lung cancer cell lines by regulating expression of apoptotic pathways and matrix metalloproteinases
}

\author{
LIJIE MA $^{1 *}$, RUIXUAN WANG ${ }^{1 *}$, YANDONG NAN ${ }^{1}$, WANGPING LI ${ }^{1}$, QINGWEI WANG $^{2}$ and FAGUANG JIN ${ }^{1}$ \\ Departments of ${ }^{1}$ Respiration and ${ }^{2}$ Pharmacy, Tangdu Hospital, Fourth Military Medical University, Xi'an 710038, P.R. China
}

Received September 10, 2015; Accepted October 20, 2015

DOI: $10.3892 / \mathrm{ijo} .2015 .3304$

\begin{abstract}
Non-small cell lung cancer (NSCLC) accounts for $80-85 \%$ of all lung cancer cases and the prognosis of NSCLC patients is unsatisfactory since 5-year survival rate of NSCLC is still as low as $11 \%$. Natural compounds derived from plants with few or no side effects have been recognized as alternative or auxiliary cure for cancer patients. Phloretin is such an agent possessing various pharmacological activities; however, there is scarce information on its anticancer effects on NSCLC. It was evaluated and confirmed, in the present study, that phloretin inhibited proliferation and induced apoptosis in A549, Calu-1, H838 and H520 cells in a dosedependent manner, phloretin also suppressed the invasion and migration of NSCLC cells. We further confirmed that phloretin dose-dependently suppressed the expression of Bcl-2, increased the protein expression of cleaved-caspase-3 and -9 , and deregulated the expression of matrix metalloproteinases (MMP)-2 and -9 on gene and protein levels. Besides, evaluations revealed that phloretin enhanced the anticancer effects of cisplatin on inhibition of proliferation and induction of apoptosis in NSCLC cells. Moreover, phloretin facilitated the effects of cisplatin on deregulation of Bcl-2, MMP-2 and -9, and upregulation of cleaved-caspase-3 and -9. In conclusion, the present study demonstrated that phloretin possessed anticancer effects and enhanced the anticancer effects of cisplatin
\end{abstract}

Correspondence to: Professor Faguang Jin, Department of Respiration, Tangdu Hospital, Fourth Military Medical University, Xi'an 710038, P.R. China

E-mail: jinfag@fmmu.edu.cn

Professor Qingwei Wang, Department of Pharmacy, Tangdu Hospital, Fourth Military Medical University, Xi'an 710038, P.R. China

E-mail: wqwlxy@163.com

*Contributed equally

Key words: phloretin, non-small cell lung cancer, apoptosis, migration, invasion on NSCLC cell lines by suppressing proliferation, inducing apoptosis and inhibiting invasion and migration of the cells through regulating apoptotic pathways and MMPs.

\section{Introduction}

Lung cancer is the most frequent reason for cancer related death and non-small cell lung cancer (NSCLC) accounts for $\sim 80-85 \%$ of all lung cancer cases (1). Although there has been notable progression in combination chemotherapy and surgical techniques, the prognosis of NSCLC patients is still unsatisfactory since 5-year survival rate of NSCLC with all stages and histological types is as low as $11 \%$ (2). Besides the prolonged life time, the survival quality of NSCLC patients should also be taken care of, while the high toxicity of anticancer drugs adopted in clinical first line to normal tissues and cells is an impassable barrier for cancer therapy and a heavy burden for patients to bear. It would be better if there were some methods that could improve the clinical therapy effects and relieve the pain of the patients.

Agents derived from various plants with few or no side effects have been recognized as potential alternative or auxiliary cure for cancer patients. Flavonoids, one major class of polyphenols, are well known for their antioxidant activity by eliminating reactive oxygen species (3) and chelating metal atoms $(4,5)$. There is also substantial research suggesting that flavonoids have anticancer effects (6). Phloretin [3-(4-hydroxyphenyl)-1-(2,4,5-trihydroxyphenyl)] is one of the major phenolic flavonoid glucosides (structure showed in Fig. 1) found in apples and other plants, such as Pieris japonica, Hoveniae Lignum and Loiseleuria procumbens $(7,8)$. Research has shown that phloretin possesses some pharmacological activities, such as modulating cytochrome P450 1A1 (9) and inhibiting MRP1-mediated drug transport (10). Further studies have revealed that phloretin has other biological benefits including inhibition of occurrence and progression of cancer (11).

The main effects of agents from natural products on cancer cells are correlated with inhibition of cell proliferation and induction of cell apoptosis. B-cell lymphoma-2 (Bcl-2) protein family is the best known regulator in modulating cell apoptosis which could launch an apoptotic signaling cascade (12). 
The process of apoptosis is regulated by pro-apoptotic and anti-apoptotic regulators and their complicated interactions. Bax and Bcl-2 are the most important pro-apoptotic regulators which may further activate the PI3K/AKT pathway and other pathways related to cell survival and death (13). In addition, natural agents may also affect invasion and metastasis of cancer cells by regulating matrix metalloproteinases (MMPs). Among which MMP-2 and -9 are of special concern since it has been confirmed that patients with enhanced expression of MMP-2 and/or MMP-9 would end up with a poorer prognosis (14). However, there is no research on whether phloretin regulates expression of the apoptotic regulators and MMPs so as to exhibit its anticancer effects in NSCLC.

Taking all the above into account, we hypothesized and investigated by a series of biological experiments, in the present study, that phloretin could induce cell apoptosis in NSCLC cell lines by regulating apoptotic regulators and downstream molecules, such as caspase- 3 and -9 , and inhibit the invasion and migratory abilities through modulating the expression of MMP-2 and -9. Importantly, we have confirmed, in the present study, that phloretin facilitated the anticancer effect of cisplatin on NSCLC cells by regulating the apoptotic pathway and expression of MMPs.

\section{Materials and methods}

Cell lines and culture. Human lung cancer cell lines, A549, Calu-1, H838 and H520 (purchased from the American Type Culture Collection), were maintained in RPMI-1640 or DMEM supplemented with $10 \%$ fetal bovine serum, $100 \mathrm{U} / \mathrm{ml}$ penicillin and $0.1 \mathrm{mg} / \mathrm{ml}$ streptomycin. The cells were maintained in a humidified incubator at $37^{\circ} \mathrm{C}$ with $5 \% \mathrm{CO}_{2}$. Cell lines were subcultured by enzymatic digestion with $0.25 \%$ trypsin when cells reached $\sim 70-80 \%$ confluency. All cell culture reagents were purchased from Hyclone Laboratories (Logan, UT, USA).

Viability assays. Cell viability in A549, Calu-1, H838 and H520 cells was measured by the mitochondrial conversion of MTT to a colored product. Briefly, cells were seeded in 96-well plates at a density of $1 \times 10^{4}$ cell/well and allowed to attach overnight in a $\mathrm{CO}_{2}$ incubator. Cells were treated with different dose of phloretin, cisplatin or combined adoption of the two agents for 24,48 or $72 \mathrm{~h}$. After that, $10 \mu \mathrm{l}$ of MTT $(5 \mathrm{mg} / \mathrm{ml}$, dissolved in PBS and filtered through a $0.22-\mathrm{mm}$ membrane) was added into each well and incubated at $37^{\circ} \mathrm{C}$ for $4 \mathrm{~h}$ before DMSO was added into each well to dissolve farmazan crystals, and absorbance was determined at $492 \mathrm{~nm}$ on an automated Bio-Rad 550 micro-plate reader (Bio-Rad Laboratories Ltd., Shanghai, China). The percentage of viable cells was determined by the formula: ratio $=[\mathrm{OD}$ (phloretin $/$ cisplatin / phloretin + cisplatin) - OD (Blank)] / [OD (Control) - OD (Blank)]. The assay was carried out in 3 independent experiments.

Analysis of apoptosis by flow cytometry. A549 and Calu-1 cells stimulated by phloretin, cisplatin or combination of the two agents were analyzed by Annexin V-FITC/PI staining (Keygen Biotech, Jiangsu, China) in order to confirm their apoptotic rate. Briefly, $2 \times 10^{5}$ cells in the exponential growth

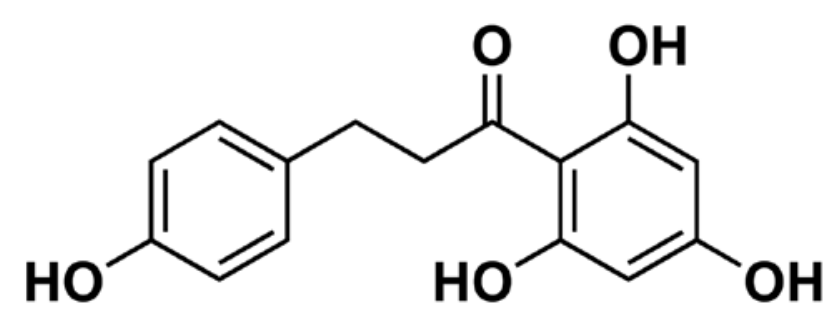

Figure 1. The structure of phloretin.

Table I. The sequence of primers used in the present research.

\begin{tabular}{ll}
\hline Sequence & \multicolumn{1}{c}{ Primers } \\
\hline$\beta$-actin-F & 5'-CCTGTACGCCAACACAGTGC-3' \\
$\beta$-actin-R & 5'-ATACTCCTGCTTGCTGATCC-3' \\
Bcl-2-F & 5'-CCAGGCCGGCGACGACTTCTC-3' \\
Bcl-2-R & 5'-ATCTCCCGGTTGACGCTCTCCACA-3' \\
MMP-2-F & 5'-CACGCTGGGCCCTGTCACTCCT-3' \\
MMP-2-R & 5'-TGGGGCCTCGTATACCGCATCAAT-3' \\
MMP-9-F & 5'-TGCCCGGACCAAGGATACAGTTT-3' \\
MMP-9-R & 5'-AGGCCGTGGCTCAGGTTCAGG-3' \\
\hline
\end{tabular}

phase were seeded in 6-well plates. Cells were treated with or without specified drugs for $24 \mathrm{~h}$ at $37^{\circ} \mathrm{C}$. Then, both adherent and floating cells were collected and analyzed by flow cytometry according to the manufacturer's instructions. Pelleted cells were gently washed with PBS 3 times and resuspended in Annexin binding buffer. Then, cells were incubated with Annexin V-FITC and PI for $15 \mathrm{~min}$ at room temperature. The stained cells were analyzed by using flow cytometry (Becton-Dickinson, San Jose, CA, USA). Cells with no drug treatment were taken as controls.

Wound healing assays. $\mathrm{H} 838$ and $\mathrm{H} 520$ cells were seeded into a 6-well plate and cultured to a confluent monolayer. A sterile $200-\mu 1$ pipette tip was used to scratch the monolayer to form wounds with equal width in each well. H838 and 520 cells were then incubated in serum-containing medium ( $2 \%$ serum) with phloretin ( 40 and $50 \mu \mathrm{g} / \mathrm{ml}$ ) for $24 \mathrm{~h}$. Images of wound areas were taken at 0 and $24 \mathrm{~h}$ at $\times 100$ magnification.

Invasion assay. The in vitro invasive ability of $\mathrm{H} 838$ and $\mathrm{H} 520$ cells was tested by the $6.5-\mathrm{mm}$ Transwell with an $8.0-\mu \mathrm{m}$ pore polycarbonate membrane insert (Corning Co., USA). The Matrigel (Becton-Dickinson and Co., USA) was incubated in the upper chamber of the Transwell system and allowed to form a gel at $37^{\circ} \mathrm{C}$. Cells $\left(3 \times 10^{5}\right)$ suspended in $300 \mu 1$ of serum-free medium were seeded into the upper compartments of each chamber in the presence of phloretin, while the lower compartments of each chamber were filled with $500 \mu 1$ medium with $10 \%$ FBS. The non-invasive cells were gently removed away from the upper surface of the membrane after $24 \mathrm{~h}$ of incubation at $37^{\circ} \mathrm{C}$. Cells on the reverse side were stained with $0.1 \%$ crystal violet and counted in five randomly selected fields under a microscope at $\mathrm{x} 400$ magnification. 


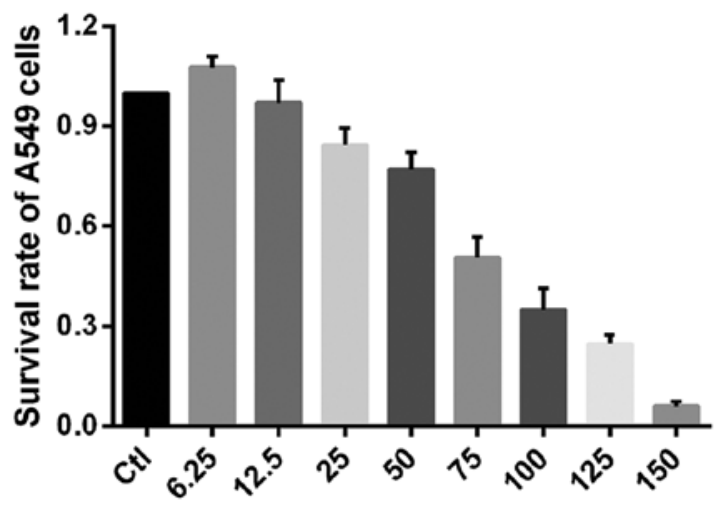

Phloretin: $\mu \mathrm{g} / \mathrm{ml}$

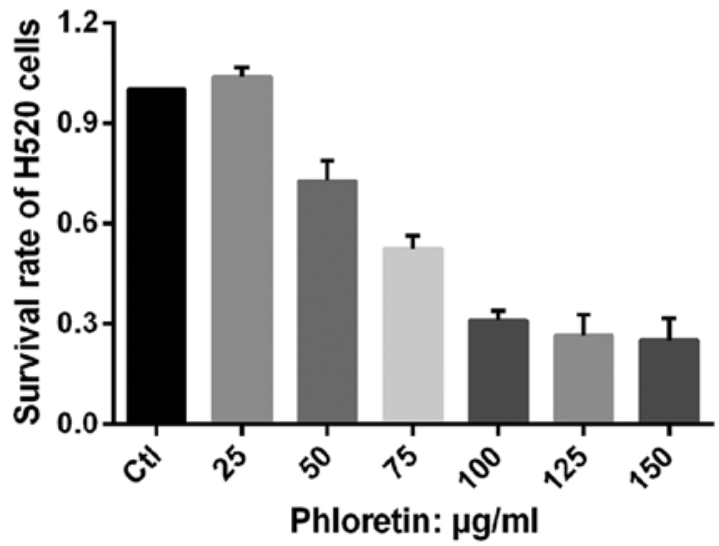

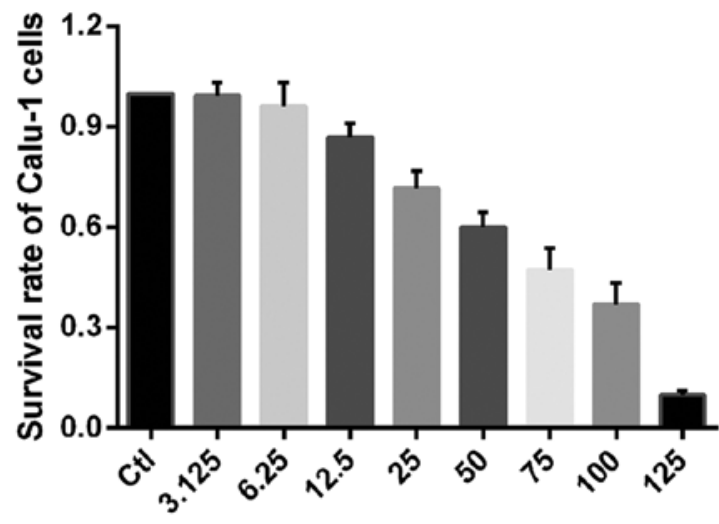

Phloretin: $\mu \mathrm{g} / \mathrm{ml}$

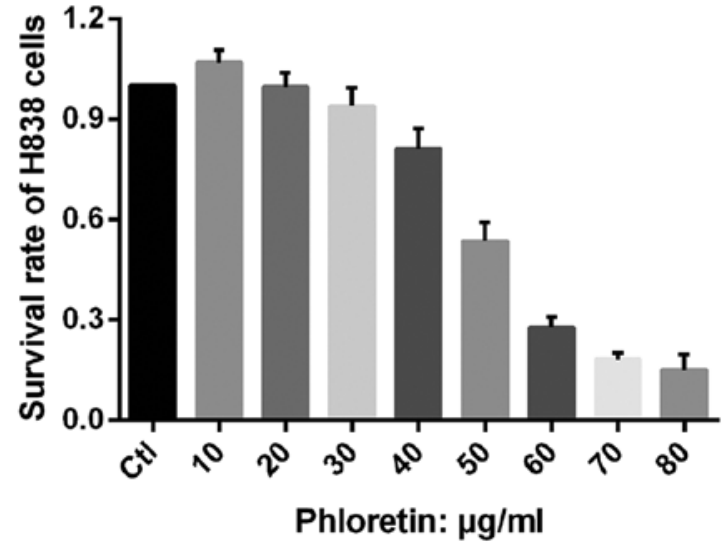

Figure 2. Effects of phloretin on the proliferation of NSCLC cells determined by MTT assay. Results, expressed by mean \pm SD, revealed that phloretin inhibited the proliferation of A549, Calu-1, H838 and H520 cells in a dose-dependent manner after 24 h of exposure.

Real-time polymerase chain reaction $(P C R)$ analysis. Total mRNA was isolated from H838 and H520 cells in the exponential growth phase with TRIzol reagent (Invitrogen, USA) according to the manufacturer's instructions. RNAs $(1 \mu \mathrm{g}$ per reaction) were reverse-transcribed to yield first-strand cDNA using transcriptase (Takara Biotechnology Co., Dalian, China), diluted cDNA was then mixed with pairs of specific primers (sequences showed in Table I) and SYBR Green PCR Master Mix (Takara) in a 20- $\mu 1$ total volume. The PCR cycling conditions were as follows: $5 \mathrm{~min}$ at $95^{\circ} \mathrm{C}$ for 1 cycle, $30 \mathrm{sec}$ at $95^{\circ} \mathrm{C}$, and $1 \mathrm{~min}$ at $60^{\circ} \mathrm{C}$ for 45 cycles. Every cDNA sample was run three times independently and the primers of $\beta$-actin mRNA, and the expression of the gene of interest was determined by the $2^{-\Delta \Delta \mathrm{CT}}$ method.

Western blot analysis. Cytosolic and nuclear proteins from H838 and H520 cells were extracted according to instructions of protein extraction kit (Beyotime Institute of Biotechnology, Jiangsu, China), and concentration of these proteins was determined by BCA method (Beyotime). Equal amount of protein from each group was separated on $8 \%$ SDS-polyacrylamide gel electrophoresis, and transferred to PVDF membrane (Millipore, MA, USA). The membranes were soaked in blocking buffer [5\% skimmed milk melted in TBS-T [25 mM Tris (pH 7.6), $138 \mathrm{mM} \mathrm{NaCl}$ and $0.05 \%$ Tween-20) for $2 \mathrm{~h}$ and then probed with Bax, cleaved caspase-3, cleaved caspase- 9 and $\beta$-actin $(1: 1,000-1: 5,000)$ (Santa Cruz, CA, USA) overnight at $4{ }^{\circ} \mathrm{C}$. The membranes were further incubated with anti-rabbit $\mathrm{IgG}$ peroxidase conjugated secondary antibody $(1: 5,000)$ conjugated with HRP, then the immune-reactive signals were detected by ECL detection system (Amersham Pharmacia Biotech).

Statistical analysis. Numeric variables are expressed as means \pm SD. Statistical differences among experimental groups were performed by one-way analysis of variance (ANOVA) followed by Dunnett's test. All statistical analysis was carried out with SPSS 17.0. A value of $\mathrm{P}<0.05$ was considered to be statistically significant.

\section{Results}

Phloretin inhibits proliferation of NSCLC cells. The vitality of A549, Calu-1, H838 and H520 cells treated with different dose of phloretin was determined by MTT assay. As shown in Fig. 2, extremely low dose of phloretin enhanced proliferation of the cells, while it could also inhibit proliferation of the cells in a dose-dependent manner with varied minimum effective concentration.

Phloretin induces cell apoptosis in A549 and Calu-1 cells. In order to determine whether the cytotoxicity of phloretin was 

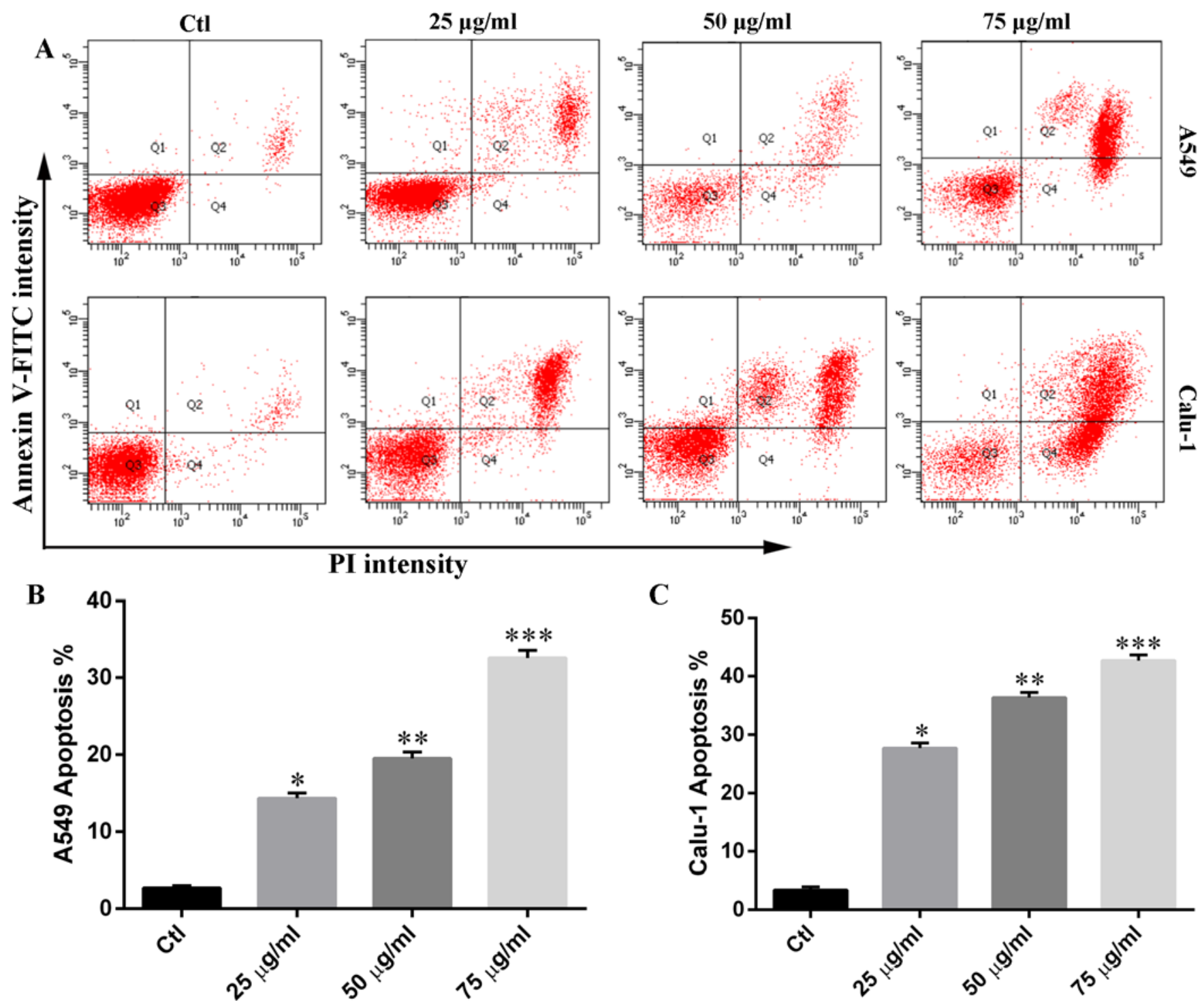

Figure 3. Phloretin induces apoptosis in A549 and Calu-1 cells as determined by flow cytometric analysis. (A) Representative flow cytometry diagram of cell apoptosis analysis. (B and C) Analysis of cell apoptosis. A549 and Calu-1 cells were treated with $0,25,50 \mathrm{or} 75 \mu \mathrm{g} / \mathrm{ml}$ of phloretin (marked with ", ${ }^{* *}$ in the graph, respectively), the results were expressed as mean $\pm \mathrm{SD}$ of separate experiments. ${ }^{*} \mathrm{P}<0.05$ vs. $\mathrm{Ctl},{ }^{* * *} \mathrm{P}<0.05$

associated with cell apoptosis, we measured the percentage of Annexin V-positive and PI-positive cells in each group. As shown in Fig. 3, phloretin treatment resulted in an increased number of early-stage apoptotic H838 and H520 cells compared with that of control. The number of Annexin V and PI positive cells in experimental groups increased in a dosedependent manner.

Phloretin inhibited migratory ability of H838 and H52O cells. Wound healing assay was carried out to determine the effects of phloretin on migration of lung cancer cells. As shown in Fig. 4, H520 cells migrated and covered the wound area after $24 \mathrm{~h}$ of incubation, while phloretin treatment inhibited the migration of $\mathrm{H} 520$ cells from each edge of the wound leaving an uncovered area in the image (Fig. 4A and B). Moreover, similar results were obtained from $\mathrm{H} 838$ cells and quantitative data indicating that phloretin inhibited the migration in $\mathrm{H} 838$ cells (Fig. 4C and D).
Phloretin inhibits invasion of lung cancer cells. Transwell membrane coated with Matrigel was used to determine the invasion of lung cancer cells treated with or without phloretin. The results (Fig. 5) showed that large amount of H520 cells from control group invaded into the lower chamber of the Transwell system, while much fewer cells treated with phloretin invaded into the lower chamber compared with that of control.

Phloretin modulated expression of apoptotic regulators and executors in lung cancer cells. In order to understand the mechanism of how phloretin induced cell apoptosis in lung cancer cells, we examined the expression of apoptotic regulators on gene and protein levels. We investigated the expression of Bcl-2 (Fig. 6). The results showed that phloretin significantly decreased the expression of $\mathrm{Bcl}-2$ at both gene and protein levels in H520 (Fig. 6A and B) and H838 (Fig. 6C and D) cells. Importantly, the changes of $\mathrm{Bcl}-2$ gene 

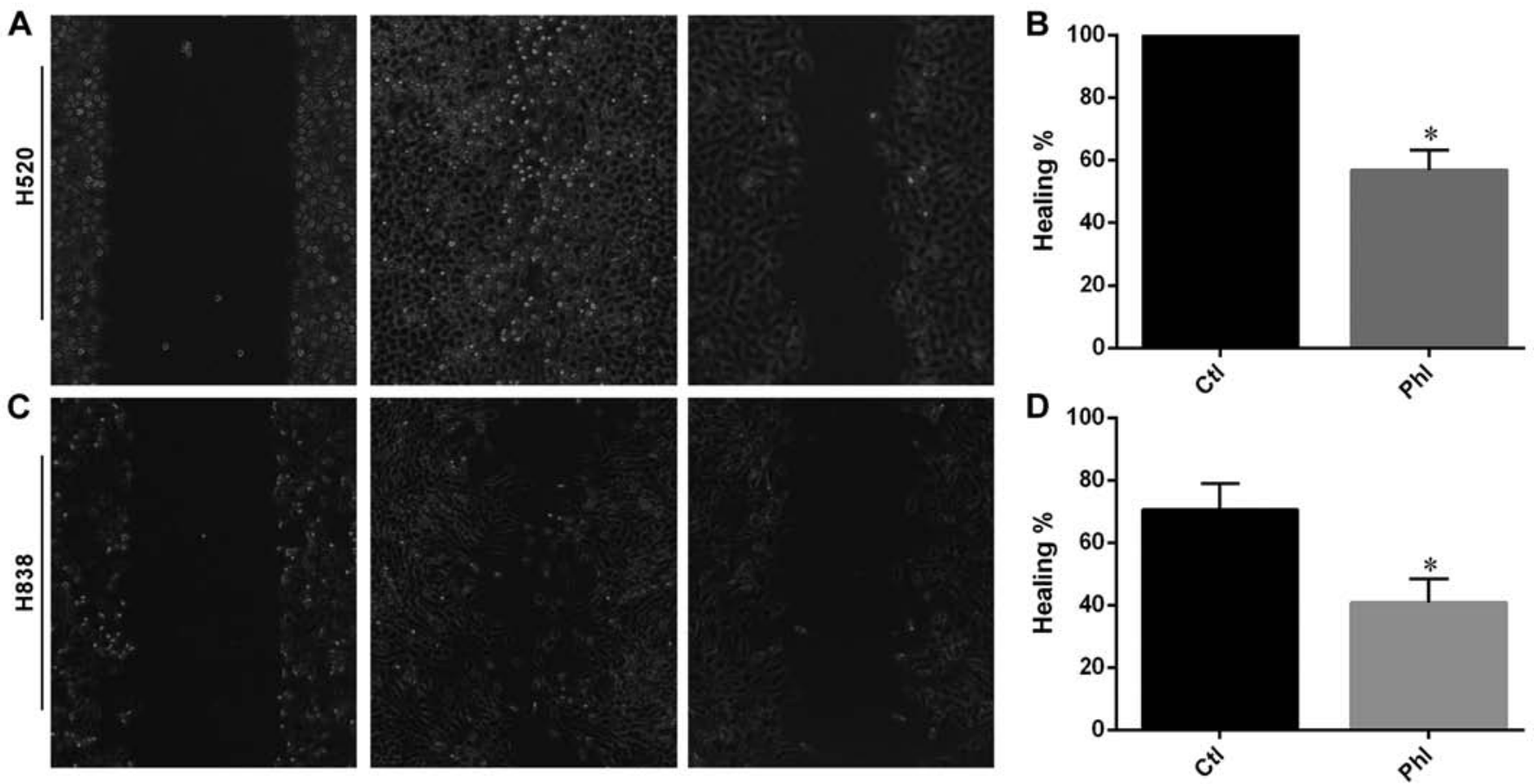

Figure 4. Effects of phloretin on migration of H520 and H838 cells was evaluated by wound healing assay. Results were semi-quantified by measuring the width of wounds. Ctl, control; Phl, $40 \mu \mathrm{g} / \mathrm{ml}$ of phloretin (marked with *) for both of the cells. "P $<0.05 \mathrm{vs}$. Ctl.
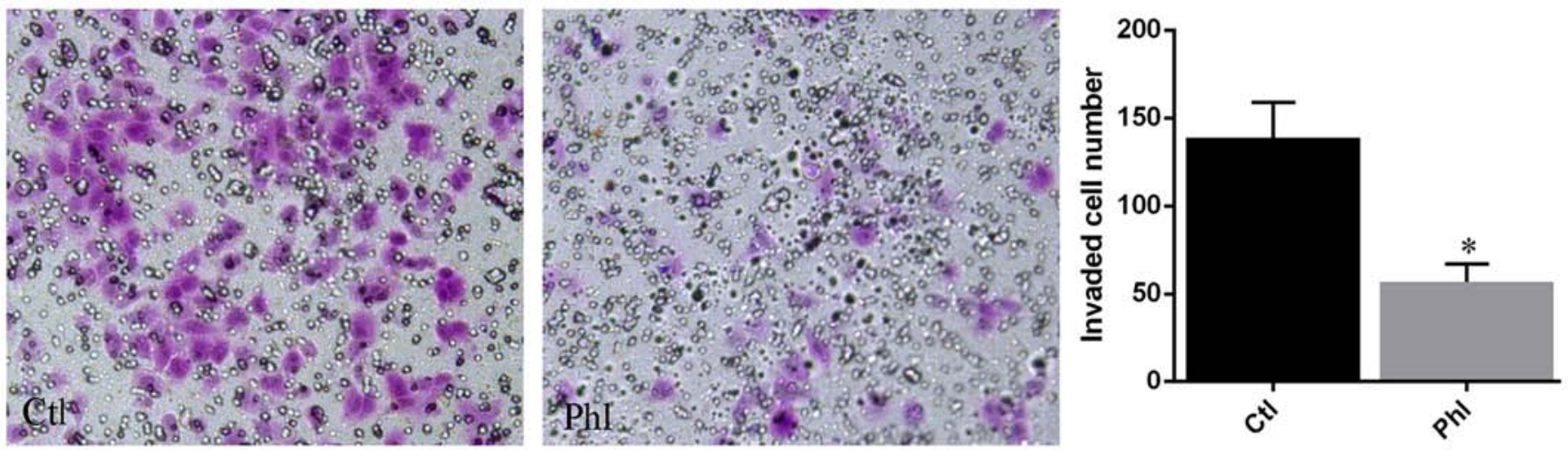

Figure 5. Effects of phloretin on invasion of H520 cells was evaluated by Transwell experiments. Cells that invaded into the lower chamber of the system were calculated and analyzed. Results were expressed by mean \pm SD. Ctl, control; Phl, $40 \mu \mathrm{g} / \mathrm{ml}$ of phloretin (marked with *) for H520 cells. "P<0.05 vs. Ctl.

and protein expression was obviously dose-dependent in the two cell lines treated with phloretin. Further, we evaluated the expression of apoptosis executors, caspase- 3 and -9 , and results showed that expression of cleaved-caspase- 3 and -9 in H520 (Fig. 7A) and H838 (Fig. 7B) cells were upregulated by phloretin dose-dependently.

Phloretin decreases the expression of MMP-2 and -9. In order to illustrate the mechanisms underlying the suppression of migration and invasion by phloretin in H838 and H520 cells, we evaluated the expression of MMP- 2 and -9 on both gene and protein levels in cells treated with different doses of phloretin. The results showed that phloretin inhibited the gene expression of MMP-2 and -9 in H520 (Fig. 8A and B) and H838 (Fig. 8C and D) cells, and the results revealed a clear dose-dependent manner in the changes of MMP-2 and -9 gene expression. Moreover, results of MMP-2 and -9 protein expressions in phloretin treated H520 and H838 cells revealed a similar trend to that of gene expression.

Phloretin enhances the effects of cisplatin on cell proliferation and apoptosis. After confirming that phloretin could inhibit proliferation of cancer cells in a dose-dependent manner, we investigated whether phloretin could facilitate the anticancer effects of cisplatin. MTT test was carried out in cells treated with phloretin, cisplatin and combined adoption of the two agents. The results showed that cisplatin inhibited the proliferation of A549, Calu-1, H838 and H520 cells in a dosedependent manner (Fig. 9A-D), more importantly, combined adoption of cisplatin and phloretin exhibited a much better effects than that of individual usage of the two agents (Fig. 9E and F). 

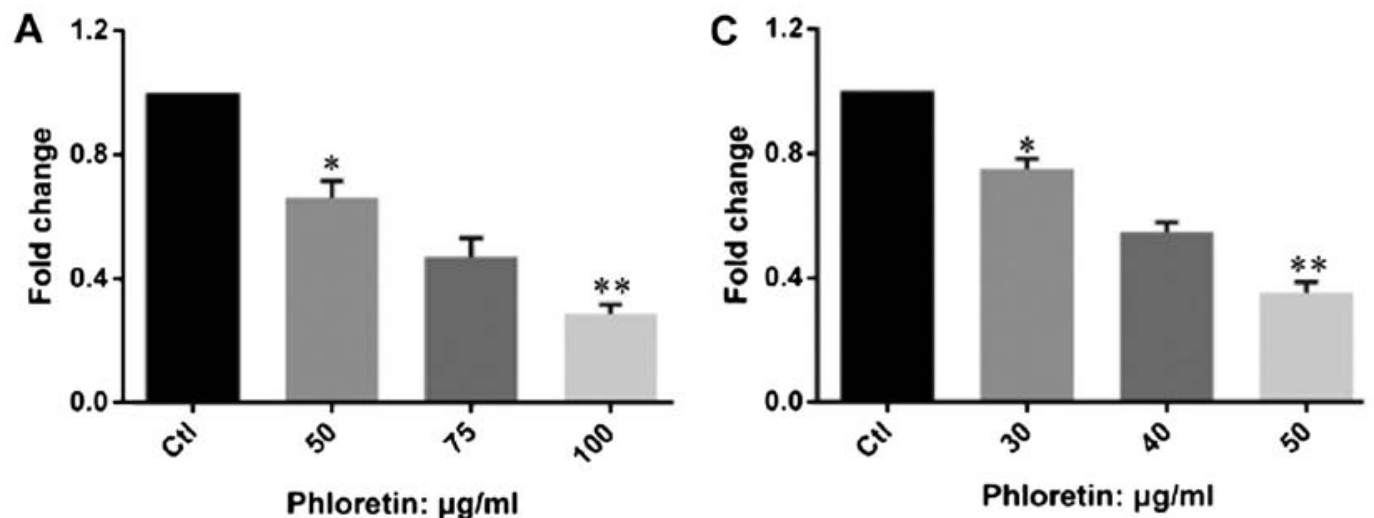

Phloretin: $\mu \mathrm{g} / \mathrm{ml}$
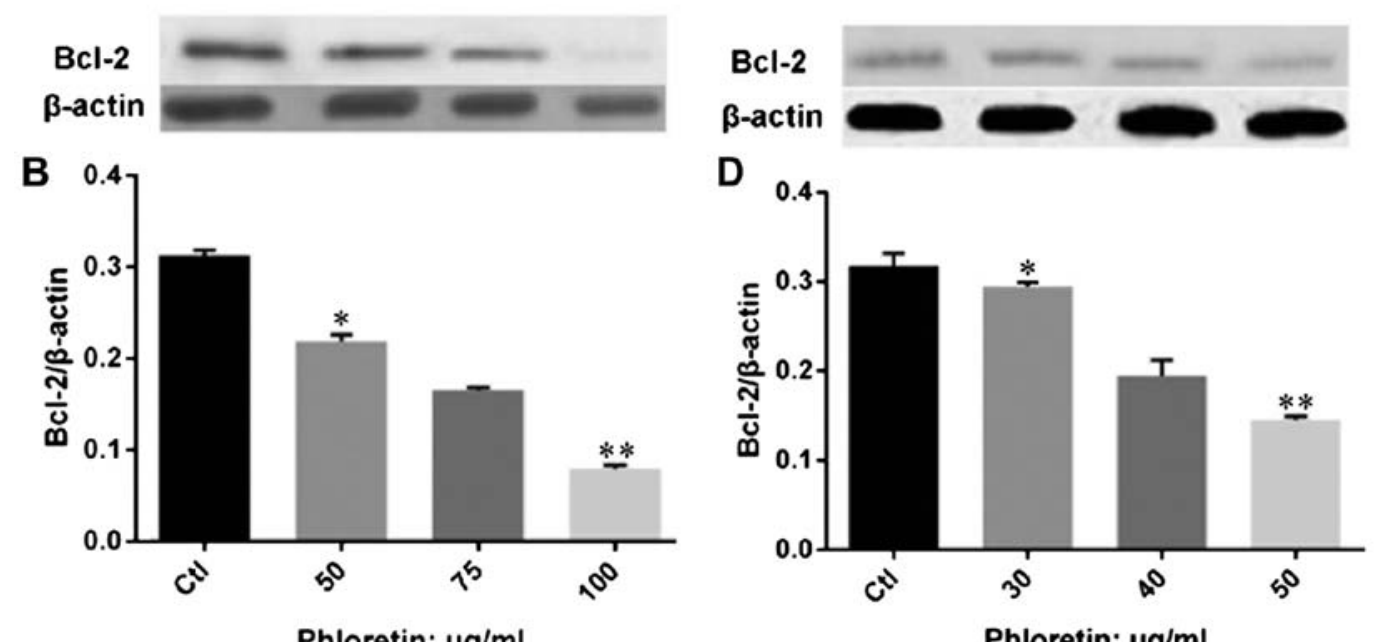

Figure 6. Expression of Bcl-2 was determined by real-time PCR and western blot analyses. (A and B) Gene and protein expression of Bcl-2 in H520 cells treated with 0,5075 and $100 \mu \mathrm{g} / \mathrm{ml}$ of phloretin (results from cells treated with 50 and $100 \mu \mathrm{g} / \mathrm{ml}$ of phloretin are marked with ${ }^{*}$ and ${ }^{* *}$ ). C and D) Gene and protein expression of Bcl-2 in $\mathrm{H} 838$ cell treated with 0, 30,40 and $50 \mu \mathrm{g} / \mathrm{ml}$ of phloretin (results from cells treated with 50 and $100 \mu \mathrm{g} / \mathrm{ml}$ of phloretin are marked with ${ }^{*}$ and $\left.{ }^{* *}\right)$. Quantitative results are expressed by mean $\pm \mathrm{SD},{ }^{*} \mathrm{P}<0.05$ vs. $\mathrm{Ctl},{ }^{*} \mathrm{P}<0.05$ vs. ${ }^{* *} \mathrm{P}$.
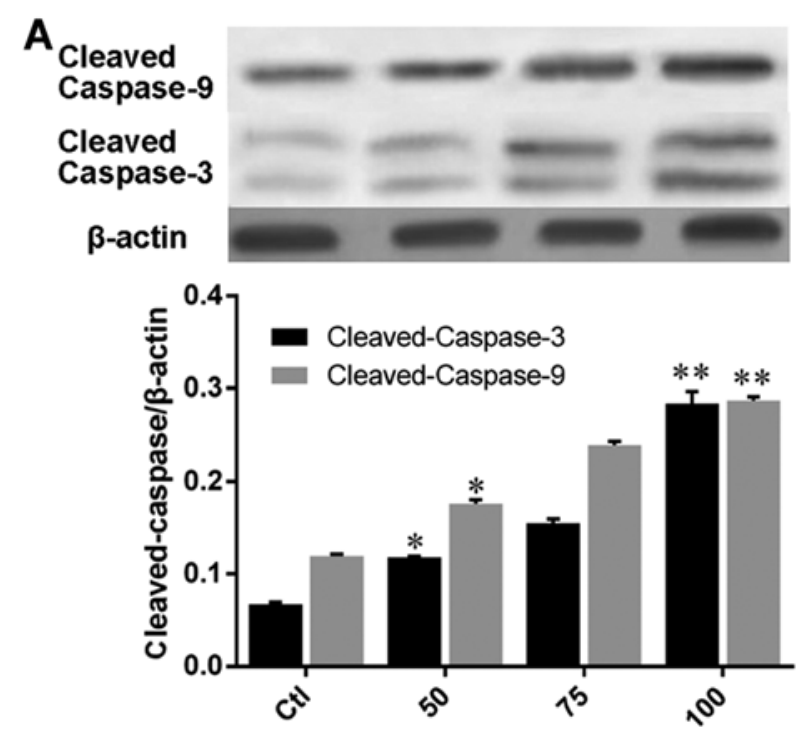

Phloretin: $\mu \mathrm{g} / \mathrm{ml}$

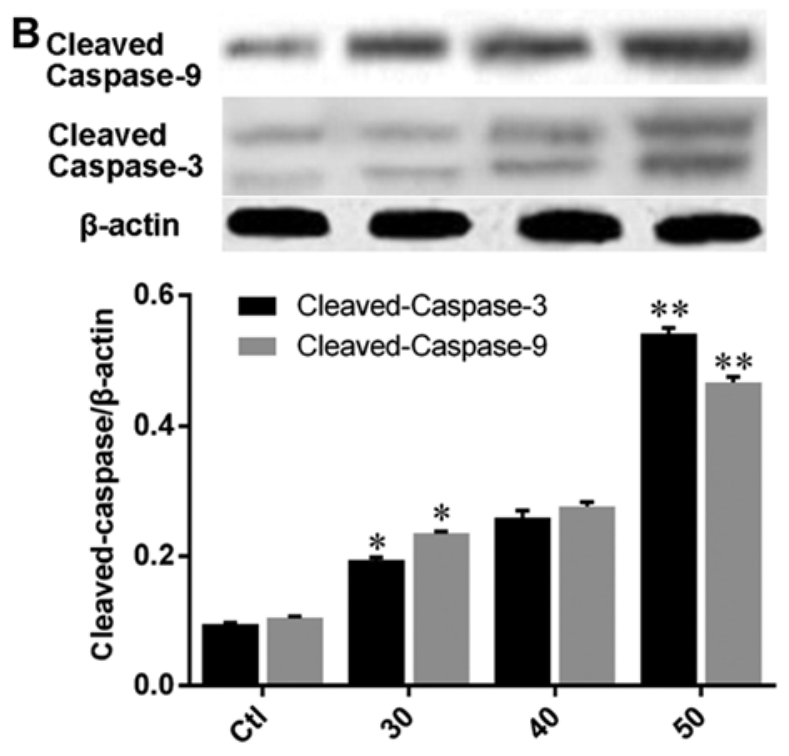

Phloretin: $\mu \mathrm{g} / \mathrm{ml}$

Figure 7. Expression of caspase-3 and -9 in H520 (A) cells treated with 50, 75 or $100 \mu \mathrm{g} / \mathrm{ml}$ of phloretin (results from cells treated with 50 and $100 \mu \mathrm{g} / \mathrm{ml}$ of phloretin are marked with ${ }^{*}$ and $^{* *}$ ), and H838 (B) cells treated with 30,40 or $50 \mu \mathrm{g} / \mathrm{ml}$ of phloretin (results from cells treated with 30 and $50 \mu \mathrm{g} / \mathrm{ml}$ of phloretin are marked with " and ${ }^{* *}$ ) were evaluated by western blot analysis. Relative expression levels of caspase-3 and -9 are expressed by comparing with that of $\beta$-actin. ${ }^{*} \mathrm{P}<0.05$ vs. Ctl, ${ }^{*} \mathrm{P}<0.05$ vs. ${ }^{* *} \mathrm{P}$. 


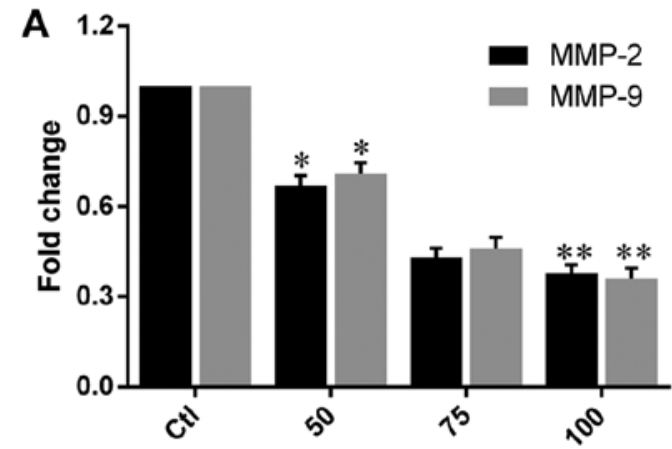

Phloretin: $\mu \mathrm{g} / \mathrm{ml}$
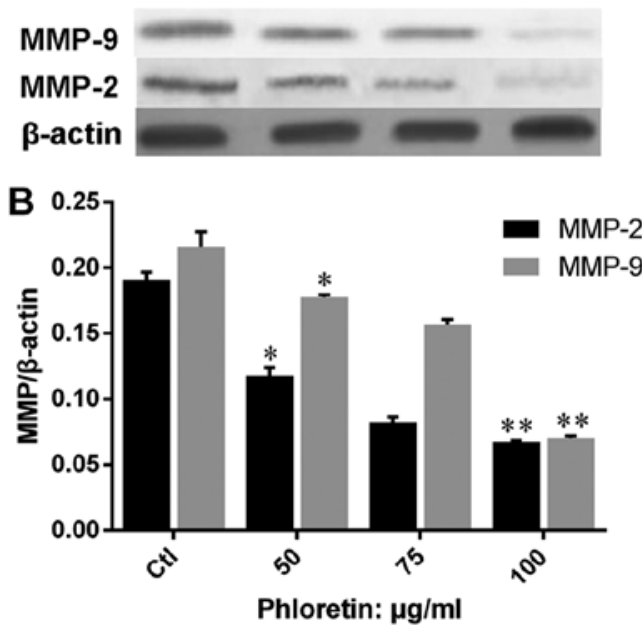

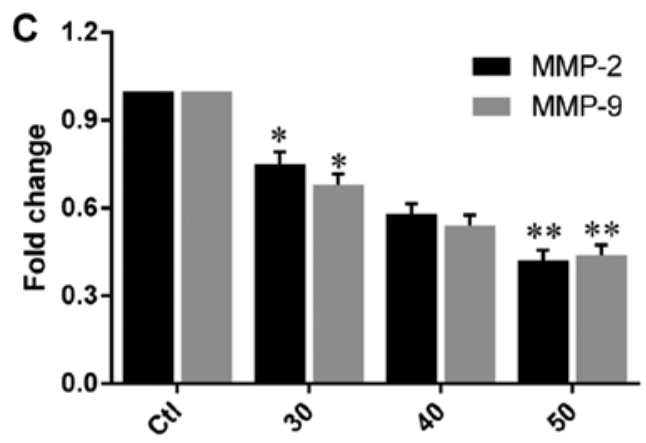

Phloretin: $\mu \mathrm{g} / \mathrm{ml}$
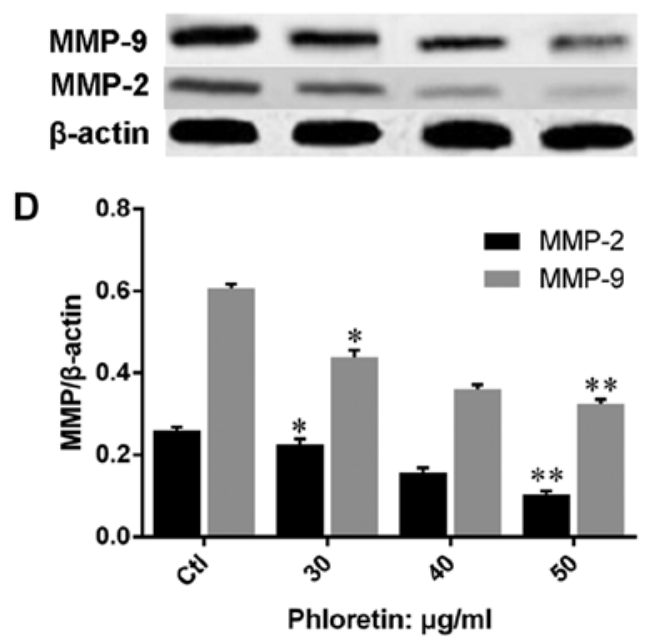

Figure 8. Expression of MMP-2 and -9 was determined by real-time PCR and western blot analysis. (A and B) Gene and protein expression of MMP-2 and -9 in H520 cells stimulated with 50,75 or $100 \mu \mathrm{g} / \mathrm{ml}$ of phloretin (results from cells treated with 50 and $100 \mu \mathrm{g} / \mathrm{ml}$ of phloretin are marked with * and $\left.{ }^{* *}\right)$. (C and D) Gene and protein expression of MMP-2 and -9 in H838 cells treated with 30,40 or $50 \mu \mathrm{g} / \mathrm{ml}$ of phloretin (results from cells treated with 30 and $50 \mu \mathrm{g} / \mathrm{ml}$ of phloretin are marked with ${ }^{*}$ and $\left.{ }^{* *}\right)$. Quantitative results are expressed by mean $\pm \mathrm{SD},{ }^{*} \mathrm{P}<0.05$ vs. Ctl, ${ }^{*} \mathrm{P}<0.05$ vs. ${ }^{* *} \mathrm{P}$.

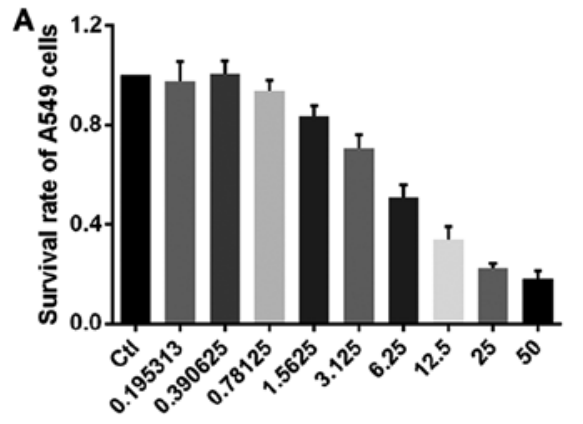

Cisplatin: $\mu \mathrm{g} / \mathrm{ml}$

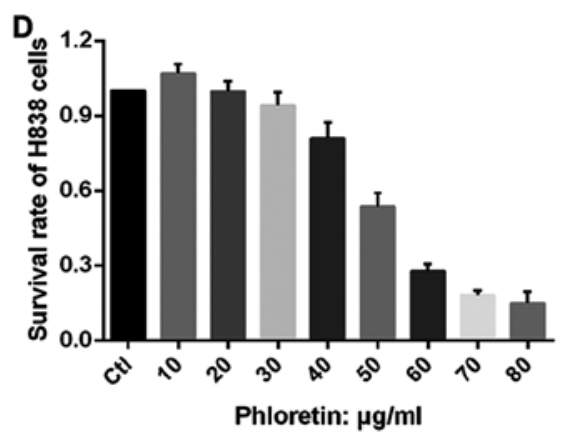

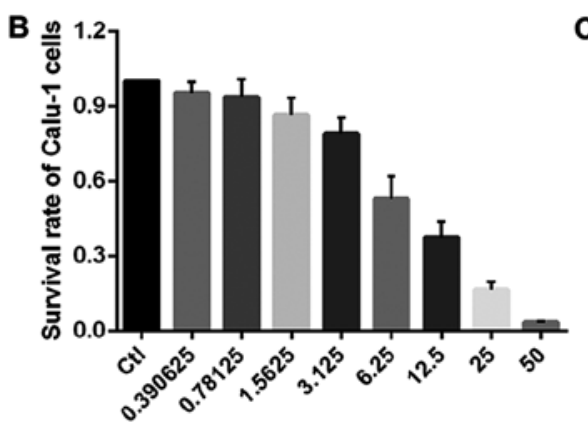

Cisplatin: $\mu \mathrm{g} / \mathrm{ml}$

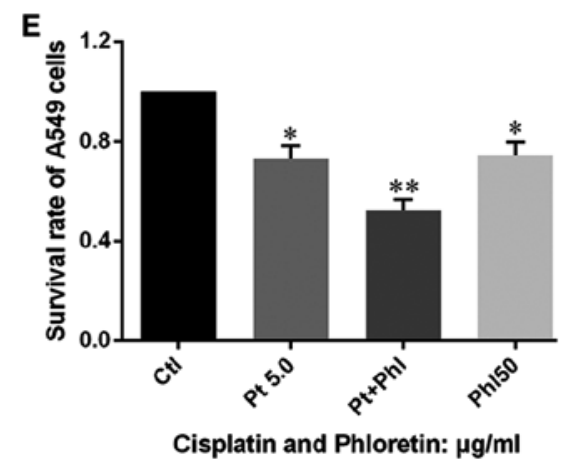

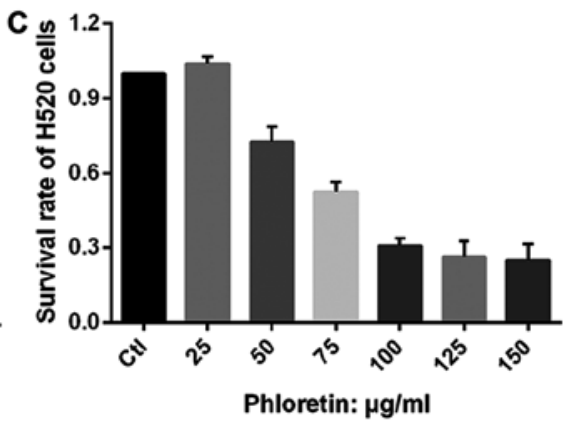

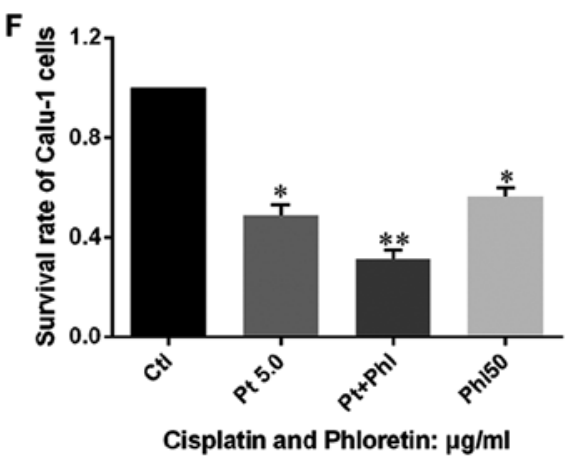

Figure 9. Effects of cisplatin combined with or without phloretin on the proliferation of NSCLC cell lines are determined by MTT assay. Results are expressed by mean \pm SD. Cisplatin inhibited the proliferation of A549 (A), Calu-1 (B), H520 (C) and H838 (D) cells in a dose-dependent manner. Combination effects of phloretin and cisplatin on A549 and Calu-1 cells are shown in (E) and (F), survival rates were compared from cells treated with phloretin or cisplatin (marked with ${ }^{*}$ ) and cells treated with cisplatin and phloretin in combination (marked with ${ }^{* *}$ ). ${ }^{*} \mathrm{P}<0.05$ vs. Ctl, ${ }^{*} \mathrm{P}<0.05$ vs. ${ }^{* *} \mathrm{P}$. 
A

CtI

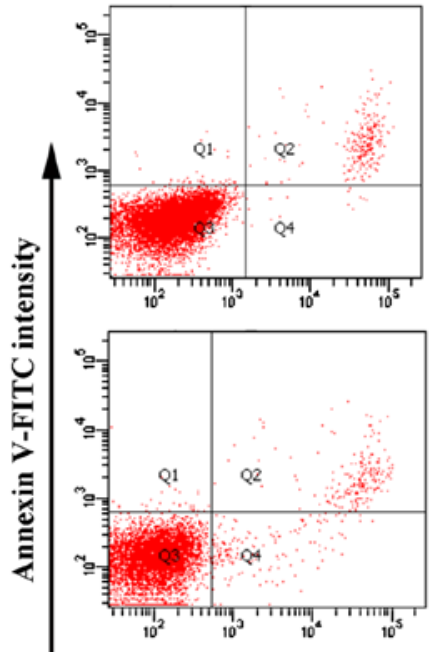

Cialplatin
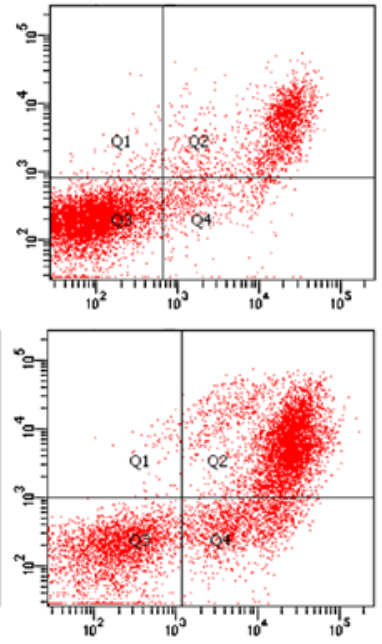

PI intensity

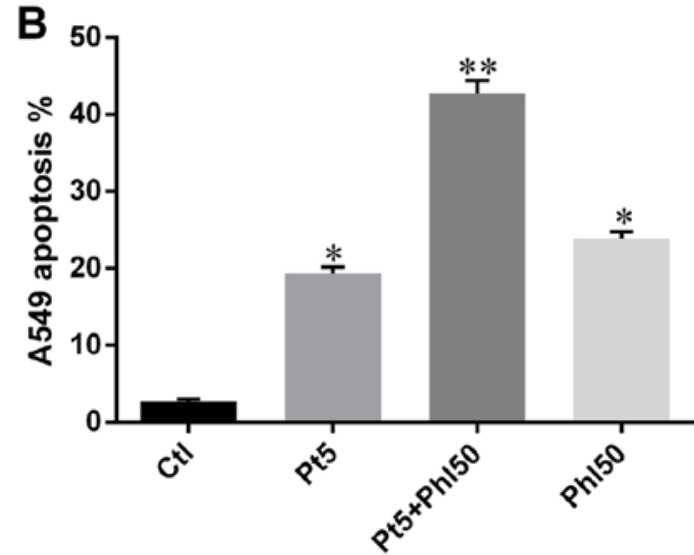

Cisplatin and Phloretin: $\mu \mathrm{g} / \mathrm{ml}$
Cisplatin+phloretin
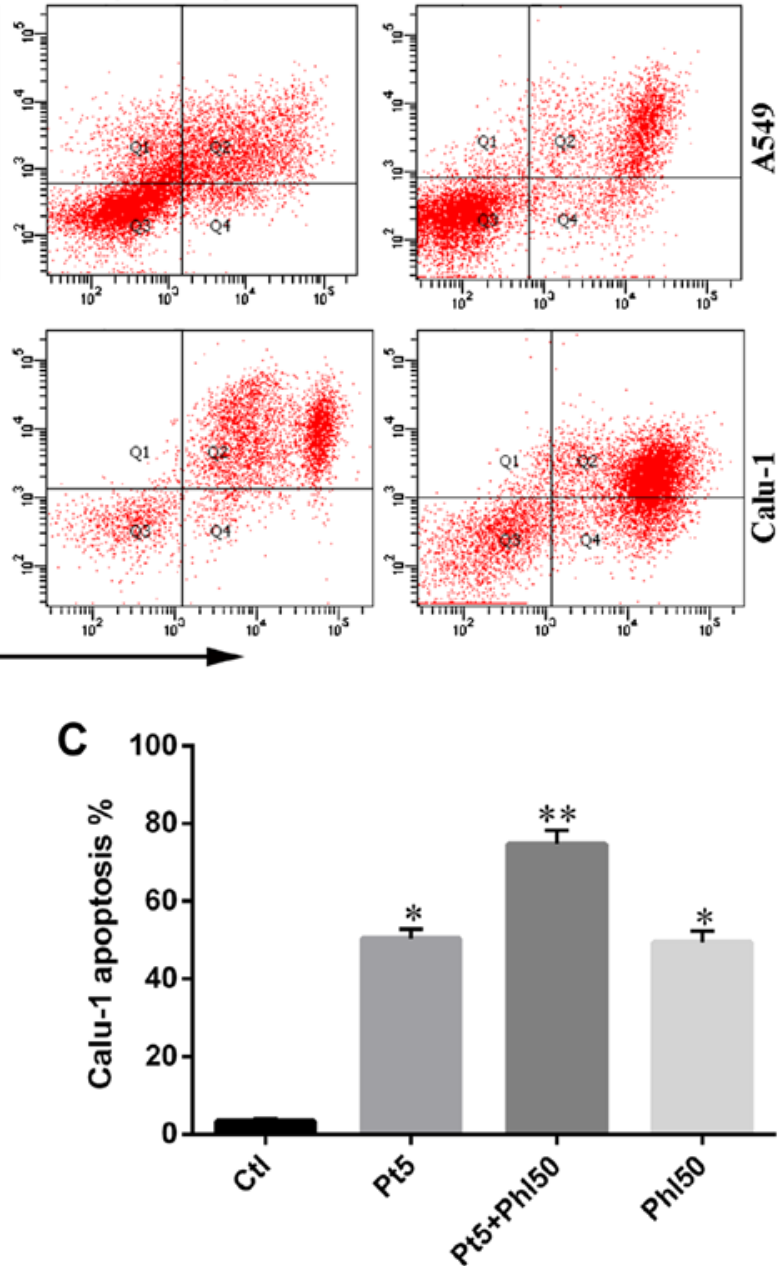

Cisplatin and Phloretin: $\mu \mathrm{g} / \mathrm{ml}$

Figure 10. Phloretin increases the amount of cell apoptosis induced by cisplatin in A549 and Calu-1 cells. (A) Representative flow cytometry diagram of cell apoptosis analysis. (B and C) Analysis of cell apoptosis. A549 and Calu- 1 cells were treated with $5 \mu \mathrm{g} / \mathrm{ml}$ cisplatin, $50 \mu \mathrm{g} / \mathrm{ml} \mathrm{phloretin}$ or $5 \mu \mathrm{g} / \mathrm{ml}$ and $50 \mu \mathrm{g} / \mathrm{ml}$ in combination. The results are expressed as the mean $\pm \mathrm{SD}$ of separate experiments. ${ }^{*} \mathrm{P}<0.05 \mathrm{vs}$. Ctl, ${ }^{*} \mathrm{P}<0.05$ vs. ${ }^{* * *} \mathrm{P}$.

A
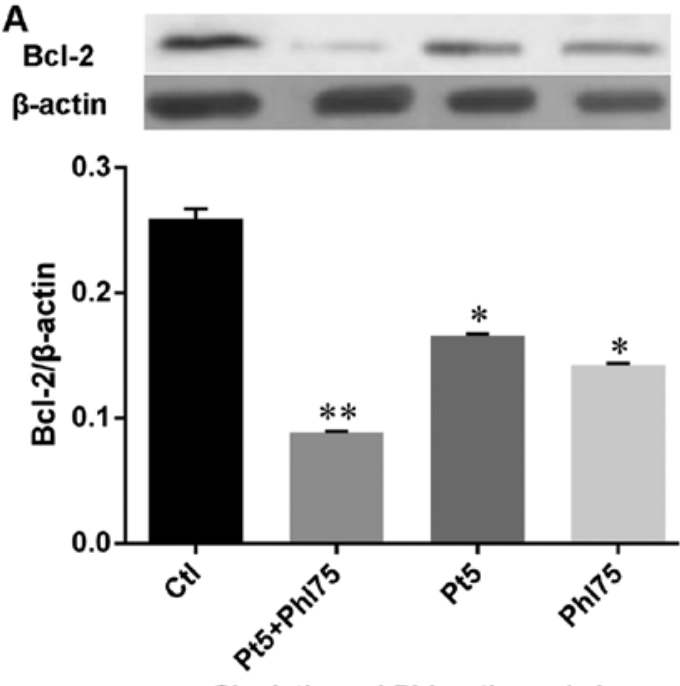

Cisplatin and Phloretin: $\mu \mathrm{g} / \mathrm{ml}$
B

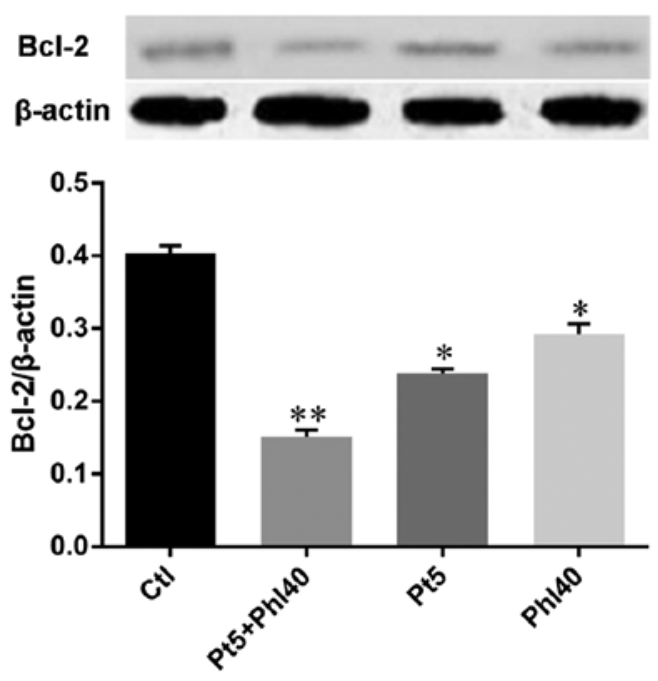

Cisplatin and Phloretin: $\mu \mathrm{g} / \mathrm{ml}$

Figure 11. Expression of Bcl-2 in H520 (A) cells treated with $5 \mu \mathrm{g} / \mathrm{ml}$ cisplatin, $75 \mu \mathrm{g} / \mathrm{ml}$ phloretin or $5 \mu \mathrm{g} / \mathrm{ml}$ cisplatin combined with $75 \mu \mathrm{g} / \mathrm{ml} \mathrm{phloretin}$, and $\mathrm{H} 838$ (B) cells treated with $5 \mu \mathrm{g} / \mathrm{ml}$ cisplatin, $40 \mu \mathrm{g} / \mathrm{ml}$ phloretin or $5 \mu \mathrm{g} / \mathrm{ml}$ cisplatin combined with $40 \mu \mathrm{g} / \mathrm{ml}$ phloretin. Ctl, control; Pt, cisplatin; Phl, phloretin; $\mathrm{Pt}+\mathrm{Phl}$, phloretin + cisplatin. Relative expression level of $\mathrm{Bcl}-2$ is expressed by comparing with that of $\beta$-actin. ${ }^{*} \mathrm{P}<0.05$ vs. Ctl, ${ }^{*} \mathrm{P}<0.05$ vs. ${ }^{* *} \mathrm{P}$. 
A
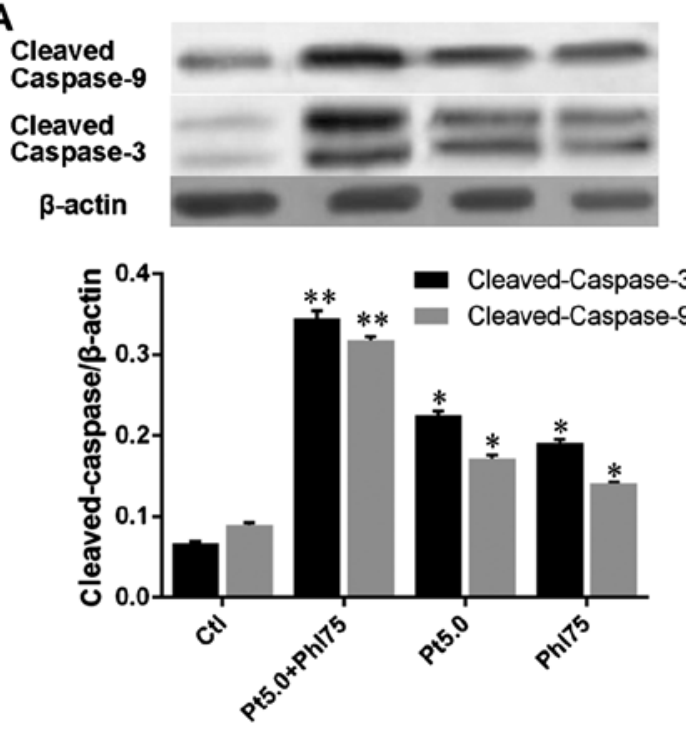

Cisplatin and Phloretin: $\mu \mathrm{g} / \mathrm{ml}$
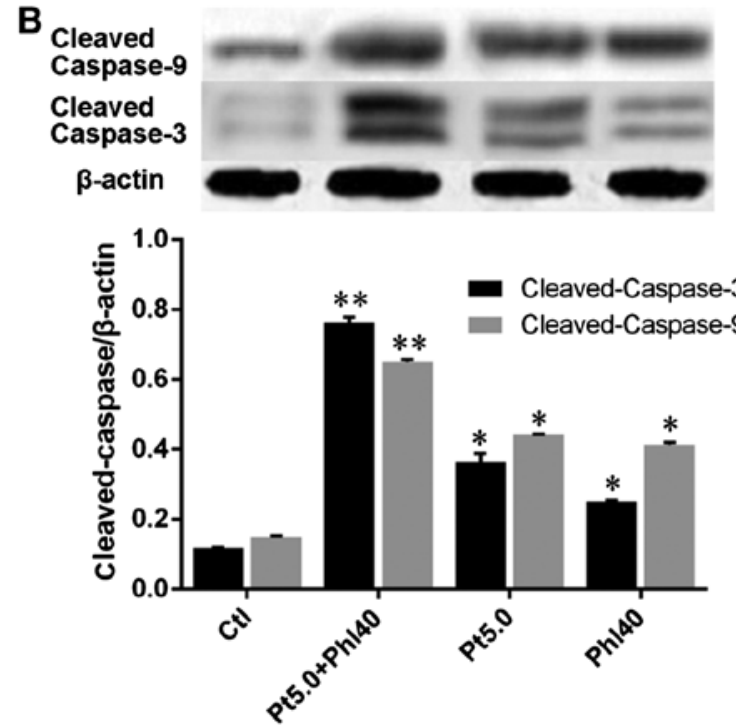

Cisplatin and Phloretin: $\mu \mathrm{g} / \mathrm{ml}$

Figure 12. Expression of caspase-3 and -9 in $\mathrm{H} 520$ (A) cells treated with $5 \mu \mathrm{g} / \mathrm{ml}$ cisplatin, $75 \mu \mathrm{g} / \mathrm{ml}$ phloretin or $5 \mu \mathrm{g} / \mathrm{ml}$ cisplatin combined with $75 \mu \mathrm{g} /$ $\mathrm{ml}$ phloretin, and H838 (B) cells treated with $5 \mu \mathrm{g} / \mathrm{ml}$ cisplatin, $40 \mu \mathrm{g} / \mathrm{ml}$ phloretin or $5 \mu \mathrm{g} / \mathrm{ml}$ cisplatin combined with $40 \mu \mathrm{g} / \mathrm{ml} \mathrm{phloretin}$ ). Ctl, control; Pt, cisplatin; Phl, phloretin; $\mathrm{Pt}+\mathrm{Phl}$, phloretin + cisplatin. Relative expression levels of caspase-3 and -9 are expressed by comparing with that of $\beta$-actin. ${ }^{*} \mathrm{P}<0.05$ vs. Ctl, ${ }^{*} \mathrm{P}<0.05$ vs. ${ }^{* *} \mathrm{P}$.

A
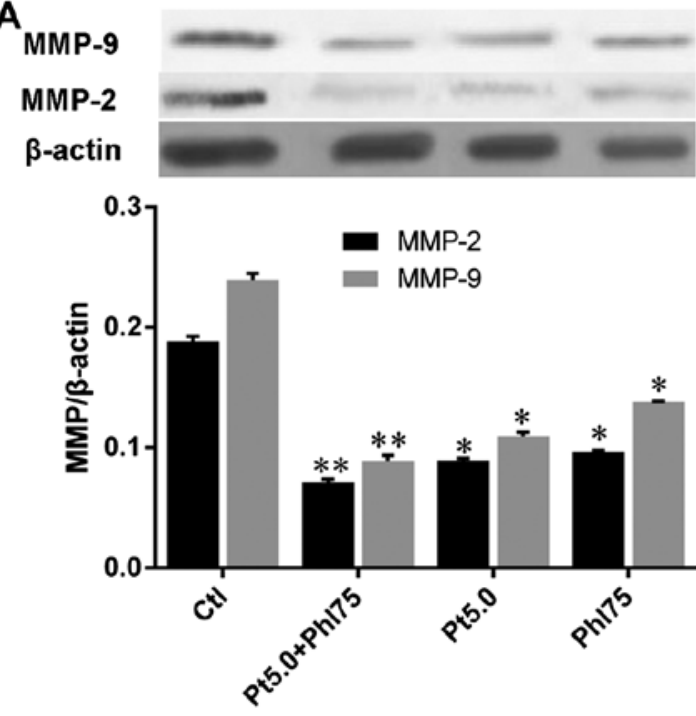

Cisplatin and Phloretin: $\mu \mathrm{g} / \mathrm{ml}$
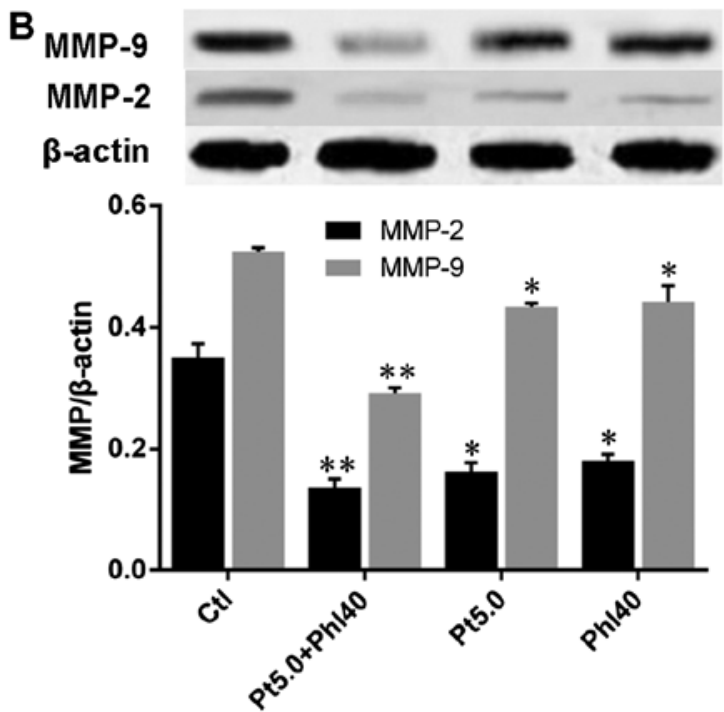

Cisplatin and Phloretin: $\mu \mathrm{g} / \mathrm{ml}$

Figure 13. Expression of MMP-2 and -9 in H520 (A) cells treated with $5 \mu \mathrm{g} / \mathrm{ml}$ cisplatin, $75 \mu \mathrm{g} / \mathrm{ml}$ phloretin or $5 \mu \mathrm{g} / \mathrm{ml} \mathrm{cisplatin} \mathrm{combined} \mathrm{with} 75 \mu \mathrm{g} / \mathrm{ml}$ phloretin, and H838 (B) cells treated with $5 \mu \mathrm{g} / \mathrm{ml}$ cisplatin), $40 \mu \mathrm{g} / \mathrm{ml}$ phloretin) or $5 \mu \mathrm{g} / \mathrm{ml}$ cisplatin combined with $40 \mu \mathrm{g} / \mathrm{ml} \mathrm{phloretin}$. Ctl, control; Pt, cisplatin; Phl, phloretin; $\mathrm{Pt}+\mathrm{Phl}$, phloretin + cisplatin. Relative expression levels of MMP- 2 and -9 are expressed by comparing with that of $\beta$-actin. ${ }^{*} \mathrm{P}<0.05$ vs. $\mathrm{Ctl},{ }^{*} \mathrm{P}<0.05$ vs. ${ }^{* *} \mathrm{P}$.

Furthermore, the results from flow cytometry showed that combined adoption of the two agents led to more apoptosis in A549 and Calu-1 cells than individual usage of phloretin and cisplatin (Fig. 10), which was in consistent with results from MTT assay.

Phloretin facilitats the modulation of cisplatin on apoptotic regulators and executors. Based on the knowledge that phloretin would enhance the effects of cisplatin on cell proliferation and apoptosis, we further investigated the expression of Bcl-2 in cells treated with cisplatin, phloretin and combined usage of these agents. The results (Fig. 11) showed that both cisplatin and phloretin decreased expression of Bcl-2, while combined adoption of the two agents decreased $\mathrm{Bcl}-2$ much more strongly in H520 (Fig. 11A) and H838 (Fig. 11B) cells. Further, we evaluated the effects of phloretin and cisplatin on the expression cleaved-caspase-3 and -9 . The results showed that combined adoption of the two agents also exhibited a better effect than individual usage of cisplatin and phloretin in H520 (Fig. 12A) and H838 (Fig. 12B) cells. 
Phloretin enhances modulation of cisplatin on MMP-2 and -9. We also investigated the effects of phloretin on the regulation of cisplatin on MMP-2 and -9 by western blot analysis. The results showed that both cisplatin and phloretin decreased MMP-2 and -9 protein expression, and combined adoption of cisplatin and phloretin would lead to a much sharper decrease of MMP-2 and -9 in H520 (Fig. 13A) and H838 (Fig. 13B) cells than that of individual treatment with cisplatin, or phloretin.

\section{Discussion}

Chemotherapy is one of the most important options for NSCLC and this therapeutic process is also a heavy burden for patients. Agents derived from various plants have been considered as potential alternative or auxiliary cure for cancer patients because research has shown that these therapeutic agents had no side effects, or at least the side effects were much more moderate compared with that of clinical first line chemotherapeutics. The anticancer effects of phloretin have been confirmed in various cancers (15-17), while its anticancer effects and underlying mechanisms on NSCLC is still uncertain. The aim of the present study was to evaluate the anticancer effects of phloretin on NSCLC cell lines and the results revealed that phloretin could exert anticancer effects on NSCLC cell lines and it also enhanced the anticancer effects of cisplatin.

In order to elucidate the effects of phloretin on cell vitality, MTT assay and flow cytometry were, respectively, carried out. MTT results showed that phloretin inhibited proliferation of A549, Calu-1, H838 and H520 cells in a dose-dependent manner while flow cytometry also indicated its apoptosis-induction ability in H838 and H520 cells, these results were consistent with previous research reporting the anticancer effects of phloretin on colon cancer cells (18). As we know, the imbalance between proliferation and apoptosis leads to limitless cell proliferation which is the hallmark of cancers. Induction of apoptosis in cancer cells has been one of the main targets for cancer therapy (19). Bcl-2 family is a pivotal regulator of cell survival and apoptosis, $\mathrm{Bcl}-2$ was the first discovered death regulator which could enhance cell survival and proliferation and inhibited expression of Bcl-2 indicating restricted cell proliferation and accelerated cell apoptosis (20). Our results have shown that phloretin induced apoptosis in NSCLC H838 and H520 cells accompanied with dose-dependently decreased Bcl-2 expression. Decreased expression of Bacl-2 would lead to upregulation of proapoptotic molecules, such as Bax, and release of cytochrome $c$ from mitochondria into cytosol followed by activation of caspase, especially caspase-3 and -9 (21). The results from the present study showed that phloretin treatment enhanced the expression of caspase- 3 and -9 followed by upgraded cell apoptosis, which was consistent with previous research indicating that caspases played a pivotal part in final common pathway of cell apoptosis (22). These results indicated that phloretin triggered cell apoptosis in NSCLC cells by inhibiting the expression of $\mathrm{Bcl}-2$ and enhancing the activity of caspase- 3 and -9 .

Metastasis is a remarkable characteristic of malignant tumors and also the primary cause of cancer-related death in most cancer patients. Previous studies have indicated that complex mechanisms were involved in the metastasis of cancers (23), among which the changed expression of MMPs, especially MMP-2 and -9 , were leading causes $(24,25)$. Enhanced expression and upgraded activity of MMP-2 and -9 resulted in degradation of extracellular matrix and destruction of basilar membrane, which facilitated the migration of cancer cells $(26,27)$. On the contrary, restricted expression of MMP-2 and -9 in cancer cells leads to a better prognosis (28-30). The results from the present study showed that exposure of NSCLC H520 cells to phloretin led to decreased invasion and migratory ability. In order to illustrated the underlying mechanism of this phenomenon, we detected the expression of MMP-2 and -9 on both gene and protein levels. The results showed that phloretin treatment decreased the expression of MMP-2 and -9 in H838 and H520 cell lines, which illustrated the primary role of MMP-2 and -9 in the inhibition effects of phloretin on lung cancer metastasis.

Based on the findings that phloretin exhibited its anticancer effects by regulating apoptotic regulators and MMPs, we were interested whether this natural product could enhance the therapeutic effects of first line drugs. We then evaluated the vitality of NSCLC A549, Calu-1, H838 and H520 cells treated by cisplatin combined with or without phloretin. The MTT results showed that cisplatin treatment suppressed proliferation of the cells in a dose-dependent manner, and combined adoption of cisplatin and phloretin exhibited a much greater inhibition effect on proliferation of $\mathrm{H} 838$ and $\mathrm{H} 520$ cells than that of single adoption of the two agents. Furthermore, combined usage of cisplatin and phloretin also led to more apoptosis in H838 and H520 cells compared with that of cells treated with cisplatin or phloretin alone. Further examinations on expressions of apoptotic regulators showed that combined usage of cisplatin and phloretin led to sharper decrease in Bcl-2 expression compared with that of cells treated with cisplatin or phloretin. Besides, combined adoption of cisplatin and phloretin showed stronger effects on deregulating MMP-2 and -9 expression compared with the results from cells treated with cisplatin alone.

This study laid emphasis on evaluating the anticancer effects of phloretin on NSCLC cell lines and elucidated the possible mechanisms in $\mathrm{H} 838$ and $\mathrm{H} 520$ cell lines. Importantly, we proved the enhancement of phloretin on the anticancer effects of cisplatin. However, this study has several limitations. First, this study only assessed the anticancer effects of phloretin in vitro, it would be better if there were results from in vivo experiments. Second, it has been confirmed, in the present research, that phloretin exhibited its inhibition on invasion, however, there was no visual results indicating phloretin facilitated the inhibition effects of cisplatin on invasion and migration since combined adoption of cisplatin and phloretin would result in too much cell death.

In conclusion, our results confirmed for the first time that phloretin treatment could suppress cell proliferation, induce apoptosis and inhibit the invasive and migratory ability of NSCLC cells probably through regulating expression of apoptotic regulators and downstream molecules, such as caspase-3 and -9 , and modulating the activities of MMPs, especially MMP-2 and -9. Above all, results from this study indicated that phloretin enhanced the anticancer ability of cisplatin at least partly through this pathway. 


\section{Acknowledgements}

This study was supported by the National Natural Science Foundation of China (no. 81071933).

\section{References}

1. Subramaniam S, Thakur RK, Yadav VK, Nanda R, Chowdhury S and Agrawal A: Lung cancer biomarkers: State of the art J Carcinog 12: 3, 2013.

2. Verdecchia A, Francisci S, Brenner H, Gatta G, Micheli A, Mangone L and Kunkler I; EUROCARE-4 Working Group: Recent cancer survival in Europe: A 2000-02 period analysis of EUROCARE-4 data. Lancet Oncol 8: 784-796, 2007.

3. de Boer A, Vos E and Bast A: Implementation of the nutrition and health claim regulation - the case of antioxidants. Regul Toxicol Pharmacol 68: 475-487, 2014.

4. Zicker SC, Wedekind KJ and Jewell DE: Antioxidants in veterinary nutrition. Vet Clin North Am Small Anim Pract 36 : 1183-1198, 2006

5. Mandel S, Amit T, Reznichenko L, Weinreb O and Youdim MB Green tea catechins as brain-permeable, natural iron chelatorsantioxidants for the treatment of neurodegenerative disorders. Mol Nutr Food Res 50: 229-234, 2006.

6. Yang DS, Li ZL, Peng WB, Yang YP, Wang X, Liu KC, Li XL and Xiao WL: Three new prenylated flavonoids from Macaranga denticulata and their anticancer effects. Fitoterapia 103: 165-170, 2015.

7. Rezk BM, Haenen GR, van der Vijgh WJ and Bast A: The antioxidant activity of phloretin: The disclosure of a new antioxidant pharmacophore in flavonoids. Biochem Biophys Res Commun 295: 9-13, 2002.

8. Zhang S and Morris ME: Effects of the flavonoids biochanin A, morin, phloretin, and silymarin on P-glycoprotein-mediated transport. J Pharmacol Exp Ther 304: 1258-1267, 2003.

9. Pohl C, Will F, Dietrich H and Schrenk D: Cytochrome P450 1A1 expression and activity in Caco-2 cells: Modulation by apple juice extract and certain apple polyphenols. J Agric Food Chem 54: 10262-10268, 2006.

10. Nguyen H, Zhang S and Morris ME: Effect of flavonoids on MRP1-mediated transport in Panc-1 cells. J Pharm Sci 92: 250-257, 2003.

11. Boyer J and Liu RH: Apple phytochemicals and their health benefits. Nutr J 3: 5, 2004.

12. Kelly PN and Strasser A: The role of Bcl-2 and its pro-survival relatives in tumourigenesis and cancer therapy. Cell Death Differ 18: 1414-1424, 2011.

13. Xin $M$ and Deng X: Nicotine inactivation of the proapoptotic function of Bax through phosphorylation. J Biol Chem 280 10781-10789, 2005.

14. Bayramoglu A, Gunes HV, Metintas M, Değirmenci I, Mutlu F and Alatas F: The association of MMP-9 enzyme activity, MMP-9 C1562T polymorphism, and MMP-2 and -9 and TIMP-1, $-2,-3$, and -4 gene expression in lung cancer. Genet Test Mol Biomarkers 13: 671-678, 2009.

15. Yang KC, Tsai CY, Wang YJ, Wei PL, Lee CH, Chen JH, Wu CH and Ho YS: Apple polyphenol phloretin potentiates the anticancer actions of paclitaxel through induction of apoptosis in human hep G2 cells. Mol Carcinog 48: 420-431, 2009.
16. Nelson JA and Falk RE: Phloridzin and phloretin inhibition of 2-deoxy-D-glucose uptake by tumor cells in vitro and in vivo. Anticancer Res 13A: 2293-2299, 1993.

17. Nelson JA and Falk RE: The efficacy of phloridzin and phloretin on tumor cell growth. Anticancer Res 13A: 2287-2292, 1993

18. Zhu SP, Liu G, Wu XT, Chen FX, Liu JQ, Zhou ZH, Zhang JF and Fei SJ: The effect of phloretin on human $\gamma \delta$ T cells killing colon cancer SW-1116 cells. Int Immunopharmacol 15: 6-14, 2013.

19. Karunagaran D, Joseph J and Kumar TR: Cell growth regulation. Adv Exp Med Biol 595: 245-268, 2007.

20. Rong Y and Distelhorst CW: Bcl-2 protein family members: Versatile regulators of calcium signaling in cell survival and apoptosis. Annu Rev Physiol 70: 73-91, 2008

21. Park HJ, Jeon YK, You DH and Nam MJ: Daidzein causes cytochrome $c$-mediated apoptosis via the Bcl-2 family in human hepatic cancer cells. Food Chem Toxicol 60: 542-549, 2013.

22. Fennell DA: Caspase regulation in non-small cell lung cancer and its potential for therapeutic exploitation. Clin Cancer Res 11: 2097-2105, 2005

23. Balzer EM and Konstantopoulos K: Intercellular adhesion: Mechanisms for growth and metastasis of epithelial cancers. Wiley Interdiscip Rev Syst Biol Med 4: 171-181, 2012.

24. Guruvayoorappan C and Kuttan G: Amentoflavone inhibits experimental tumor metastasis through a regulatory mechanism involving MMP-2, MMP-9, prolyl hydroxylase, lysyl oxidase, VEGF, ERK-1, ERK-2, STAT-1, NM23 and cytokines in lung tissues of C57BL/6 mice. Immunopharmacol Immunotoxicol 30: 711-727, 2008.

25. Chen RX, Xia YH, Xue TC, Zhang H and Ye SL: Downregulation of osteopontin inhibits metastasis of hepatocellular carcinoma cells via a mechanism involving MMP-2 and uPA. Oncol Rep 25: 803-808, 2011.

26. Borkham-Kamphorst E, Alexi P, Tihaa L, Haas U and Weiskirchen R: Platelet-derived growth factor-D modulates extracellular matrix homeostasis and remodeling through TIMP-1 induction and attenuation of MMP-2 and MMP-9 gelatinase activities. Biochem Biophys Res Commun 457: 307-313, 2015.

27. Davis ME, Gumucio JP, Sugg KB, Bedi A and Mendias CL: MMP inhibition as a potential method to augment the healing of skeletal muscle and tendon extracellular matrix. J Appl Physiol 115: 884-891, 2013.

28. Wang R, Ke ZF, Wang F, Zhang WH, Wang YF, Li SH and Wang LT: GOLPH3 overexpression is closely correlated with poor prognosis in human non-small cell lung cancer and mediates its metastasis through upregulating MMP-2 and MMP-9. Cell Physiol Biochem 35: 969-982, 2015.

29. Xu X, Chen L, Xu B, Xie Q, Sun M, Deng X, Wu C and Jiang J: Increased MT2-MMP expression in gastric cancer patients is associated with poor prognosis. Int $\mathrm{J}$ Clin Exp Pathol 8: 1985-1990, 2015.

30. El-Badrawy MK, Yousef AM, Shaalan D and Elsamanoudy AZ: Matrix metalloproteinase-9 expression in lung cancer patients and its relation to serum MMP-9 activity, pathologic type, and prognosis. J Bronchol Interv Pulmonol 21: 327-334, 2014. 